\title{
HOW TO CREATE ISLAMIC BRANDING ON LA TANSA GONTOR DEPARTMENT STORE
}

\author{
Fajar Surya Ari Anggara ${ }^{a}$, Achmad Ihya Ulumuddin ${ }^{b}$ \\ Fakultas Ekonomi dan Manajemen, Universitas Darussalam Gontor \\ fajarsurya@unida.gontor.ac.id ${ }^{\text {al } \gg}$,ulumuddin688@gmail.com ${ }^{\text {b }}$
}

\begin{abstract}
ABSTRAK
Nilai-nilai Islam merek dapat ditentukan dalam berbagai cara, termasuk: berdasarkan faktor kepatuhan, berdasarkan asal-usulnya, dan berdasarkan pelanggan. La Tansa Gontor Department Store milik Pondok Modern Darussalam Gontor merupakan salah satu unit komersial yang dioperasikan oleh Pondok Modern Darussalam Gontor, sebuah pesantren yang menempatkan penekanan kuat pada nilai-nilai Islam. Tujuan dari penelitian ini adalah untuk menentukan bagaimana LaTansa Gontor Department Store dapat mengadopsi poin merek Islam sambil juga mengidentifikasi pendekatan yang baik. Penelitian ini menggunakan pendekatan kualitatif berdasarkan teori grounded. Informasi tersebut dihimpun melalui pengamatan, wawancara, dan dokumentasi. Pengambilan sampel purposive digunakan untuk menentukan sampel yang digunakan oleh peneliti, dan penggunaan metode analisis data Miles dan Hubberman. Menurut temuan penelitian ini, LaTansa Gontor Department Store telah berhasil menanamkan citra mereknya dalam persepsi pelanggan.
\end{abstract}

Kata kunci: Merk Islami, Strategi, Toko Serba Ada

\begin{abstract}
The brand's Islamic values can be determined in a variety of ways, including: based on factors of compliance, based on its origin, and based on the customer. Pondok Modern Darussalam Gontor's La Tansa Gontor Department Store is one of the commercial units operated by Pondok Modern Darussalam Gontor, an Islamic boarding school that places a strong emphasis on Islamic values. The goal of this study is to determine how LaTansa Gontor Department Store may adopt Islamic brand points while also identifying a good approach. This study employed a qualitative approach based on grounded theory. The information was gathered through observation, interviews, and documentation. Purposive sampling was utilized to determine the sample used by the researcher, and Miles and Hubberman's data analysis method use. According to the findings of this study, LaTansa Gontor Department Store has succeeded in instilling its brand image in customer perception.
\end{abstract}

Keywords: Islamic Brand, Strategy, Department Store

\footnotetext{
${ }^{1} \times$ : Corresponding Author: fajarsurya@ unida.gontor.ac.id
} 


\section{INTRODUCTION}

Brand has an important role for a product or service or goods. Brands are also often a tool for consumers in making decisions. In addition, the existence of a brand that is able to attract consumers to use these products. In fact, it can stand as a business pillar that supports the business itself. It is undeniable that today many companies are competing to make their brand number one or top of mind in the minds of customers.

The importance of building a brand has become a necessity for companies to be able to compete with other companies. Competition in the business world is getting tougher, making companies trying to find the right strategy in marketing their products. Business competition in its development in the era of globalization requires companies to behave and act quickly and appropriately. Therefore, every company is required to compete competitively in terms of creating and maintaining loyal customers (customers), namely through brand competition to provide a special image for its consumers.

Within and outside of the Islamic world, the practice of Islamic branding (IB) has gained substantial traction in scholarly circles in recent years. The tremendous media attention it continues to receive has resulted in the staging of multiple high-profile events throughout the world, as well as the publication of an academic magazine, the Journal of Islamic Marketing (Alserhan, 2010).

The phenomenon of many emerging Islamic brands, signifying a shift in consumer behavior. Undeniably, many consumers make the brand they buy or use, is a manifestation of themselves or in other words, they make the brand as a medium to show their identity to others. For example, in the world of banking or financial institutions, nowadays there are many sharia banks, Sharia financial institutions, sharia pawnshops. In the world of education today there are many emerging integrated Islamic elementary schools (SDIT), Integrated Islamic Kindergartens (TKIT), in the field of hotels there are hotels that implement sharia system (sharia hotels). In the field of beauty many open salon services and spas specifically serve muslim women (muslimah salon). At the wedding reception there are those who use sharia wedding or Islamic Wedding which is a wedding reception that guests separated between men and women. In Entertainment, many choose Islamic-nuanced shows or tv stations that air islamic-nuanced shows. In the field of health there are Islamic hospitals whose services use Islamic principles (Ranto, 2013).

The focus of the discussion in this paper is to discuss the existence of Islamic Branding which is currently a trend and besides that this brand is deliberately raised by producers as a strategy to attract consumer buying interest. The existence of muslim consumers on certain brands is a challenge for producers to be able to serve them. Islamic brand become popular on retail industries. Such as 212 Mart products, Ismart Ponorogo, Surya Mart, Bintang Swalayan, and Basmalah Mart as the Sidogiri Islamic Boarding School Mart.

La Tansa Gontor Department Store is owned by Pondok Modern Darussalam Gontor located in Ponorogo. This is one of several business unit on Pondok Modern Darussalam Gontor that managed by islamic business ethics such as sincerity, simplicity, self-reliance, Islamic brotherhood, and freedom (Faradisi et al., 2020). The founding fathers of Pondok Modern Darussalam Gontor, established a new pesantren system based on effective concepts of advancement and a modern educational system. Initially, they endowed practically all of the land inherited from their parents for the benefit of pesantren, which was supported by a business unit as a kind of self-sufficiency(Masqon, 2014).

The Islamic side is displayed by La Tansa on the physical aspects and activities that run in it. Like on brand image of La Tansa Gontor Department Store by the mosque's domed logo as well as the inside nuances are very close to the Islamic element. The atmosphere 
built through activities such as the cessation of activities during prayer times and so forth strengthen the image of La Tansa as an Islamic brand. Based on the research background that has been mentioned above, then the problem to be investigated by researcher is How does La Tansa Gontor Department Store build their brand based on Brand Canvas. Based on the problems to be studied, this research is expected to know the results of the following points to analyze the implementation of brand strategies conducted by La Tansa Gontor Department store.

\section{LITERATUR REVIEW Brand}

Brand is defined as the name, term, mark, symbol, design or combination of the whole intended to identify the product or service produced so that it differs from the product or service produced by the competitor. Brands are valuable because they are able to influence consumer choices or preferences. A good brand can signal the superiority of the product to consumers which leads to favorable consumer attitudes and brings better sales and financial performance for the company(Abbas et al., 2021).

Brands are defined as names, terms, symbols, special designs or combinations of such elements designed to identify products or services offered by sellers. A brand is said to be special if the consumer feels confident that the brand is really special. Aaker theory about brand is distinguishing names or symbols (such as logos, stamps, packaging) with the intention of identifying the goods or services of a particular seller or a particular group of sellers.(Zainudin et al., 2019)

Religion, although a significant component of culture, has received little attention in terms of brand personality. With the rapid rise of Islamic finance in various Muslim nations, such as Malaysia, there is a need to look at the brand personalities of Islamic businesses like banks and insurance organizations. Islamic banks and insurance companies may benefit from the proposed Islamic brand personality model (Ahmed \& Jan, 2015).

\section{Islamic Brand}

The effects of the country's image yielded outcomes that were not supported by the findings of this study. Because there is full mediation of the halal brand image through three additional variables: Halal brand perceived quality, Halal brand trust, and Halal brand loyalty, halal brand image does not have a substantial direct effect on repurchase intention (Kusnandar \& Afiff, 2020).

Internal Islamism commitment based on Islamic ideas or values has an impact on halal brand identity and also has a direct impact on halal brand loyalty. The alignment of one's Islamic self with the halal brand has an impact on one's identification with the halal brand. As a result, to encourage Muslim devotion to their halal brand (Choi \& Rahman, 2018).

Islamic branding in Malaysian food purchase, particularly items, must meet halal requirements, which has an impact on modern MMW in their daily lives, particularly when it comes to food purchases. The importance and significance of halal certification in Islamic branding, consumer behavior, advertising, and purchasing decisions in Malaysia (Hussin, 2017).

Islamic brand also can improve halal industry products. Tourism businesses can improve their brand image by upgrading their products and services from a religious standpoint, which can lead to higher customer satisfaction. Tourism firms, for example, can 
increase the quality of Islamic vacation packages and provide Muslim customers with the most up-to-date Islamic vacation packages (Nawi et al., 2019).

In another aspect, Islamic brand is a communication approach for promoting halal tourism in non-Muslim countries," according to a study conducted in South Korea. Using the document analysis method, they discovered that South Korea promotes its country as a Muslim-friendly destination by enacting certain policies. Hijab characteristics, pork and alcohol-free foods and beverages, and Muslim food suppliers are only a few examples. This halal category is defined by the South Korean government and then publicized in the form of symbols by various halal product providers in order to promote Muslim-friendly tourism in South Korea (Nisa \& Sujono, 2017).

Consumers' perceptions of Islamic branding can be influenced by factors other than items, such as the behavior of sales promotion girls in marketing Sharia-compliant products. The manner in which sales promotion ladies give services to customers may help establish a brand position(Andini \& Rufaidah, 2018).

\section{RESEARCH METHOD}

The type of research used is the qualitative research. Researcher used qualitative because researcher wants to examine more in accordance with the natural conditions of the implementation of Islamic Brand in order to obtain conclusions on the matter, so as to identify appropriate strategies to be done. This approach is designed to allow researcher to draw conclusions from random data that match the conditions in the field.

This method has a generalization of the outcomes of processes, actions and interactions in the field. Data collection in this research is by using various research instruments such as observation, interview, and documentation. Data collection aims to observe the conditions around the object, asking the resource person in depth, and then discussed again with the resource person to get stronger data. This research method is chosen by the researcher to disclose various strategic steps undertaken by the company in building an Islamic brand and how the process is formulated and applied in the field.

The location where this research is conducted is located in the management of La Tansa Gontor Department Store. La Tansa Gontor Department Store is one business unit owned by Pondok Modern Darussalam Gontor which makes it as one of the stores that has an Islamic brand. La Tansa Gontor Depatment Store located in regency of Ponorogo. La Tansa Gontor Department Store provides a variety of needs both primary and secondary ranging from food court, daily clothing, sports equipment, books and stationery, and medicines. The territory is located in the center of the crowd and one of the business unit belongs to the Boarding Schoolmakes the researcher assume that the location is very strategic and representative to conduct a research on the strategy of Islamic branding.

As for the sample used by researcher is the purposive sampling, that is data retrieval method by using a sample with a variety of specific consideration. Since the purpose of this research is to know about strategy, then the researcher determined that the subjects of this study are strategic decision makers from each sector of La Tansa Gontor Department Store that include the Chairman of La Tansa Gontor Department Store, 1 from General Coordinator of La Tansa Gontor Department Store, 2 from Manager of business sectors at La Tansa Department Store that can represent all of managers and staffs, and also 2 main customers.

The primary data source of the research was carried out from all over objects that include internal and external environment object, human resources, document, and all strategic activities undertaken by La Tansa Gontor Department Store. The primary data that has been collected is then supported by secondary data derived from opinions, photographs, 
and other data relating to the research. The collection of data necessary for researcher to obtain the data required for the analysis process. There are three instruments of research conducted in this research.

Three of these presence, face to face, or involved in a focus group and throw the question to get the views and opinions of the informant concerned.Interviews conducted by researcher in this study is a semi structured interview. A semi structured interview is a freeinterview but still in the structure determined by the researcher. In semi-structured interviews the informant was asked for ideas and the researcher recorded everything that was expressed by informants to then be summed up as data. Documents are written records, stored images, and recorded voices about everything that happens. The document is unlimited in time so as to provide space on the researcher to know everything that has happened as the affirm from the data obtained in the observation and interview. The documentation is the fact who had stored and archived in a variety of forms. In addition, researcher also used data owned by the company as secondary data as a research being conducted at La Tansa Gontor Department Store.

The analysis of qualitative data is a process for preparing the data obtained from the results of observation, interview, and various other records have been obtained systematically in order to be understood easily. The analysis of qualitative data is a process for preparing the data obtained from the results of observation, interview, and various other records which have been obtained systematically in order to be understood easily. Data analysis done by researcher using Miles \& Huberman model analysis. Miles and Huberman's model is to collect qualitative data interactively, then the reduction of data, followed by presenting the data in accordance with the pattern and take the conclusions from these data.

\section{RESULT \& DISCUSSION}

\section{Brand Name of La Tansa Gontor Department Store}

The name is an identity which will be pinned to the brand. To specify a name, a brand should do some steps to identify the source of inspiration. According to Kamal Muhtadi, the name La Tansa Gontor itself is a name with the determination of a long path where there are former names such as Darussalam, Kopontren La Tansa, etc. Finally, the name La Tansa is used. As time goes by, the name La Tansa is widely used on merchants and other stores. Even the boarding school also named the same thing in the cooperation. Then based on the decision of the foundation and the approval of Kyai, then La Tansa name was combined with the Boarding School then changed to La Tansa Gontor to inform that La Tansa is an affiliate and belongs to Pondok Modern Darussalam Gontor in Ponorogo. Andika Putra Rianda, General Coordinator of La Tansa mentions that in philosophical meaning, the name of La Tansa Gontor is actually taken from the verses of the Qur'an. In the verse that reads (Wa laa tansa nashibaka min ad-dunya) which means to not to forget your fate in the world. Then, this meaning becomes the foundation to visualizing La Tansa as an Islamic brand. This was matched by two other staffs of La Tansa. La Tansa is literally taken from Arabic which means: don't forget. La Tansa is also a trade mark which means that this business unit is selfmanaged to finance cottage activities so that the cottage can be independent not dependent on other parties.

\section{Positioning Statement of La Tansa Gontor Department Store}

Dias Satrio Wibowo states that La Tansa Gontor Department Store stands to meet the needs of santri and the community with a clear product origin. In addition, Kamal Muhtadi also agreed with Dias that La Tansa Gontor Department Store always selects and cultivates from Muslim producers. Variants and the price are also adapted as needed. It is 
also delivered by the General Coordinator of La Tansa Gontor Department Store, Andika Putra Rianda. He said that La Tansa Gontor Department Store gave a 10\% discount. The various statements made by the management of La Tansa above are also approved by consumers' opinions. Taufiq Affandi stated that the products that exist, especially the books are quite complete and safe, in accordance with the nature of education. Meanwhile, according to Fajrul Aryadi, prices in La Tansa is cheap with a discount.

\section{Brand Personality of La Tansa Gontor Department Store}

Personality of La Tansa Gontor Darussalam Gontor according to Andika as General Coordinator is the religious aspect. The atmosphere built by La Tansa Gontor Department Store has been built in such a way to form religious values. This strong religious character was also approved by other informants from staff such as Kamal Muhtadi who said that religious aspects can be reflected in the uniforms and clothing used by the staff and the music used, as well as from the views of customers such as Fajrul Aryadi and Taufiq Affandi stating the service and break during prayer time.

In addition, Kamal added that what wants to build by La Tansa Gontor Department Store is an emotional character where everyone who remembers La Tansa Gontor Department Store then remembers Gontor. This is also agreed by Dias Satrio Wibowo. In addition, Andika states that the character that wants to be built is the character of education. Both employees, staff, even consumers, have to be educated. Education on staff and employees through various activities held, while education to consumers is reflected in the restrictions of goods sold in accordance with the nature of Pondok Modern Darussalam Gontor.

\section{Persona of La Tansa Gontor Department Store}

Persona defined by La Tansa Gontor Department Store experienced some changes. At the beginning of the establishment of La Tansa Gontor Department Store is one of the business unit of Pondok Modern Darussalam Gontor which has a goal as the fulfilment of the needs of students and family of boarding school. It emphasizes that the special persona targeted by La Tansa is a consumer market the boarding school that includes santri and teachers and in-house Gontor families, whose motivating factors are merely the fulfilment of emotional needs and emotional factors that customers have in their boarding school.

After experiencing a rapid development later and became a business unit that is large enough, the persona targeted by La Tansa Gontor Department Store also changed. At the beginning, the customer targets are the student of boarding school (santri), then the current targeted persona is also among the community. Individuals in this community is the preferred community to the youth and students, from the upper middle class in Ponorogo, especially the city area, and covers all levels of society. Although it is open to the public, La Tansa still limits the goods provided in accordance with the nature of Darussalam Gontor education.

\section{Brand Storyboard of La Tansa Gontor Department Store}

According to Andika, one of the problems that has been gotten by La Tansa Gontor Departmen Store is when a customer is a student who needs a book of course materials. The customer has searched for the book in question throughout the bookstore in Ponorogo and still cannot find it. So, when consumers come to La Tansa and they have not got what they are looking for, the consumer can ask directly to the staff of La Tansa to book the book in question. After that the staff will contact the printing and publisher of the book in question to ask for stock and if the book is already available, the staff will contact the customer who 
has made the order. In addition, Taufiq Affandi told the story of finding the goods that are expected in La Tansa Gontor Department Store with good quality and price in accordance with the portion, is not too expensive and relatively cheap.

Likewise, Fajrul Aryadi who have ever found the book Tafsir Al-Azhar written by Buya Hamka in La Tansa Gontor Department Store. Another story mentioned by Dias when a consumer came during the time of prayer hour to buy medicine, but the circumstances experienced by the consumer is in an emergency. So, La Tansa Gontor Department Store continues to serve these consumers.

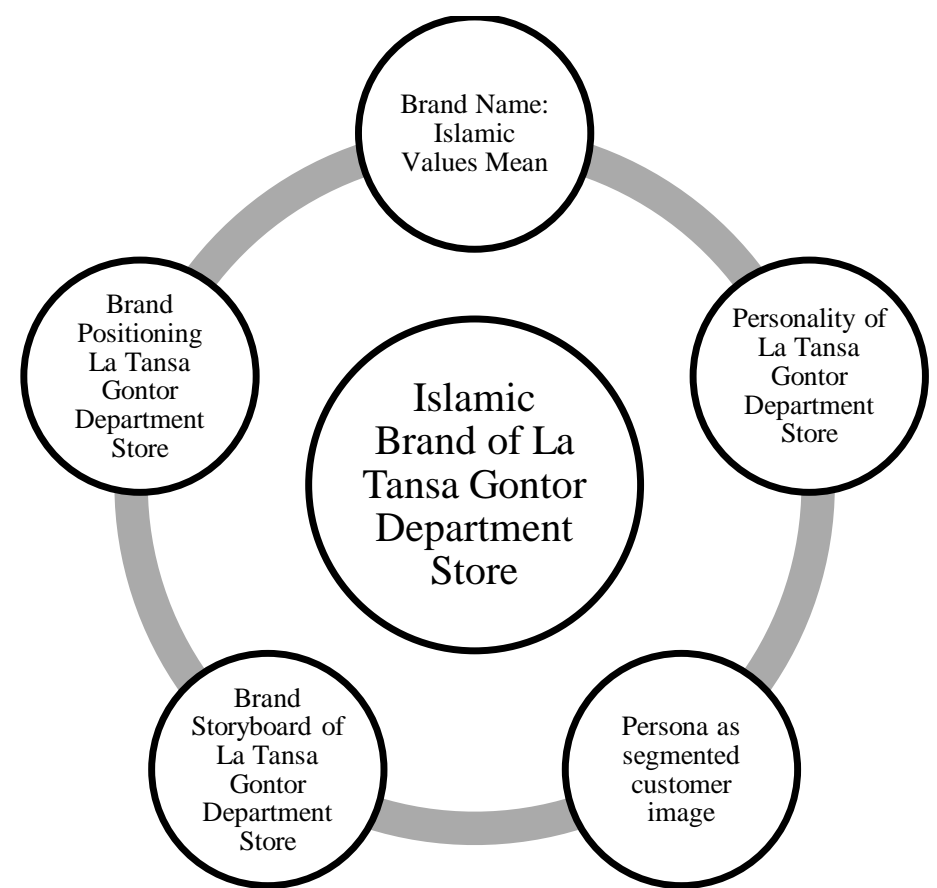

Figure 1: five aspects of Islamic Brand on La Tansa Gontor Department Store Source: data analyzed (2021)

Islamic aspects and attributes of the shop, religious values are reflected in the atmosphere, interests, products, etc. Furthermore, because of the name is affiliated with Gontor, one of its personality is the emotional value as that if remembering La Tansa Gontor then remember Gontor. Another element that is featured in La Tansa personal is the aspect of education which is reflected in the education for employees, staff, even consumers. Islamic brand resonance: integration of the brand resonance and Islamic branding concept. By qualitative with literature review approach that used in this research, the concept and value of Islamic branding must integrate with brand resonance. The resonances are in the form of a religious principle, in accordance with Sharia law, which attributes of the product (Suparno, 2017).

Kamal Muhtadi as head of line in Fashion \& Sport section La Tansa Gontor Department Store stated that the main target of consumer La Tansa Gontor Department Store is the student of boarding school (santri). This is because the establishment of La Tansa Gontor Departmen Store is as the need of the santri. In addition, another market targeted by La Tansa Gontor Department Store is the share of B2B. According to Dias Satrio Wibowo, treasurer of the La Tansa Gontor Apotek, stated that in addition to direct to the students, La Tansa also sends wholesale to outlets that become regular buyers, like BKSM for pharmacies, student coopration section for Fashion \& Sport and books. Andika Putra has an opinion that the consumers of La Tansa Gontor Department Store are general consumers 
from middle and upper class. In marketing, the concept of Islam is fluid. Unless there is a prohibition, which only applies to the tiniest details, everything can be done. This is one of the reasons why, in recent years, marketing experts have become interested in the concept of Islamic marketing. In terms of brand image, Islam has its own distinct appeal that can entice people not only financially, but also emotionally (Idris et al., 2020).

Current research show that articulating the definition of Islamic brand from an Islamic perspective is difficult. To study the similarities and contrasts of Muslim customers' opinions about a brand, most studies simply used the traditional brand definition in Western nations (Ismail \& Alias, 2016). Based on the above story, La Tansa Gontor Department Store tries to transform its commitment to the minds of its customers that La Tansa Gontor Department Store is a professional store and has various products with the price in accordance with what consumers expect. From various stories gathered from informants, La Tansa wants to show its commitment as a trusted product provider. La Tansa wants to instill a side of professionalism, quality, and care for its customers.

\section{CONCLUSION}

Islamic Branding as described earlier is not limited to the definition that the brand is the name, symbol, writing or combination of all of them. However, furthermore, in the brand contained sharia principles that are the embodiment of Islamic values. The emergence of this Islamic brand is based on the company's purpose in influencing the buying interests of consumers, especially Muslim consumers. The awareness of using products labeled Islam is also the reason today the number of emerging brands on Islamic image. The brand image built by La Tansa Gontor Department Store has been built in such a way to form religious values. Brand Name of La Tansa Gontor Department Store, La Tansa literally translates to "don't forget" from Arabic. La Tansa is also a trademark, indicating that this business unit is self-managed to fund cottage activities, allowing the cottage to be self-sufficient and not reliant on others. Brand Positioning of La Tansa Gontor Departement Store is for santri's and the community's needs are met by La Tansa Gontor Department Store, which has a definite product origin. La Tansa Gontor Department Store picks and cultivates Muslim producers at all times. Employees, workers, and even customers must be educated. Staff and employees are educated through various activities, while consumers are educated through the restrictions on goods offered in accordance with Islamic ideals to visualize brand personality. La Tansa Gontor Department Store's particular persona is a boarding school consumer market that comprises santri and teachers, as well as in-house Gontor families, whose driving elements are simply the fulfillment of emotional demands and emotional components that customers have in their boarding school. La Tansa Gontor Department Store strives to instill in the minds of its clients the belief that La Tansa Gontor Department Store is a professional store that offers a wide range of products at reasonable prices. La Tansa intends to demonstrate its commitment as a trustworthy product provider by using diverse stories acquired from informants. La Tansa wishes to imbue its consumers with a sense of professionalism, quality, and concern to strengthen the brand's storyboard.

\section{DAFTAR RUJUKAN}

Abbas, U., Islam, K. M. A., Hussain, S., Baqir, M., \& Muhammad, N. (2021). Impact of Brand Image on Customer Loyalty With the Mediating Role of Customer Satisfaction and Brand Awareness. International Journal of Marketing Research Innovation, 5(1), 1-15. https://doi.org/10.46281/ijmri.v5i1.987

Ahmed, M., \& Jan, M. T. (2015). An extension of Aaker's brand personality model from 
Islamic perspective: a conceptual study. Journal of Islamic Marketing, 6(3), 388-405. https://doi.org/10.1108/JIMA-10-2014-0068

Alserhan, B. A. (2010). On Islamic branding: Brands as good deeds. Journal of Islamic Marketing, 1(2), 101-106. https://doi.org/10.1108/17590831011055842

Andini, A. L., \& Rufaidah, P. (2018). The Influence of Islamic Branding and Religiosity on Brand Image. AFEBI Islamic Finance and Economic Review, 2(02), 31. https://doi.org/10.47312/aifer.v2i02.111

Choi, N. H., \& Rahman, M. M. (2018). Muslim consumer's identification with and loyalty to halal brand. Journal of Distribution Science, 16(8), 29-37. https://doi.org/10.15722/jds.16.8.201808.29

Faradisi, R. J., Surya, F., \& Anggara, A. (2020). Analysis of Islamic business ethics and its impact during the Covid19 pandemic. 6(3), 115-120.

Hussin, R. (2017). The Awareness of Islamic Branding among Modern Malay Muslim Women (MMW). International Journal of Academic Research in Business and Social Sciences, 7(13), 70-82. https://doi.org/10.6007/ijarbss/v7-i13/3185

Idris, M., Maupa, H., Muis, M., \& Pono, M. (2020). Membangun Konsep Brand Religiosity Image Dalam Islamic Marketing (Sintesis Teori dan Penelitian Empiris yang Relevan). Jurnal Ilmiah Ekonomi Islam, 6(1), 14-21. https://doi.org/10.29040/jiei.v6i1.929

Ismail, M. S. I. Bin, \& Alias, N. B. (2016). Islamic Brand: A Conceptual Definition of Brand from Islamic Perspective. Journal of Islamic Studies and Culture, 4(2), 59-71. https://doi.org/10.15640/jisc.v4n2a6

Kusnandar, A., \& Afiff, A. Z. (2020). The role of the country's image and halal branding constructs in influencing repurchase intentions. European Journal of Molecular and Clinical Medicine, 7(1), 3995-4009.

Masqon, D. (2014). Dynamic of Pondok Pesantren As Indegenous Islamic Education Centre in Indonesia. EDUKASI: Jurnal Penelitian Pendidikan Agama Dan Keagamaan, 12(1), 134-142. https://doi.org/10.32729/edukasi.v12i1.78

Nawi, N. B. C., Al Mamun, A., Nasir, N. A. M., Abdullah, A., \& Mustapha, W. N. W. (2019). Brand image and consumer satisfaction towards Islamic travel packages. Asia Pacific Journal of Innovation and Entrepreneurship, 13(2), 188-202. https://doi.org/10.1108/apjie-02-2019-0007

Nisa, F. K., \& Sujono, F. K. (2017). Islamic branding as communication strategy of halal tourism promotion in non-Muslim country. Proceeding of The 4th Conference on Communication, Culture and Media Studies, October, 7-14. https://doi.org/10.5350/dajpn2010230209t

Ranto, D. W. P. (2013). Menciptakan Islamic Branding Sebagai Stretegi Menarik Minat Beli Konsumen. Jbma, I(2), 1-11.

Suparno, C. (2017). Menggagas Model Islamic Brand Resonance : Integrasi Konsep Brand Resonance Dan Islamic Branding. Prosiding Seminar Nasional \& Call For Papers 2017 Optimalisasi Tata Kelola Organisasi Dalam Upaya Peningkatan Daya Saing Dan Iklim Investasi, 156-161.

Zainudin, M. I., Haji Hasan, F., \& Othman, A. K. (2019). Halal brand personality and brand loyalty among millennial modest fashion consumers in Malaysia. Journal of Islamic Marketing, August. https://doi.org/10.1108/JIMA-10-2018-0187 